\title{
对新时代基层水文测验工作的思考
}

\author{
王姝 '杨晓亮 \\ 1 天津市龙网科技发展有限公司 2 进洪闸水文站
}

DOI:10.32629/hwr.v3i12.2559

[摘 要] 本文针对进入新时代,基层水文测验面临的新机遇、新挑战,遵循 “水利工程补短板,水利行业强监管” 水利改革总基调,发扬 “忠诚干 净担当科学求实创新” 的新水利精神,贯彻 “节水优先,空间均衡,系统治理,两手发力” 的治水思路,探求如何提升基层水文测验工作水平,提升 基层水文测验队伍建设。

[关键词] 新时代; 基层; 水文测验; 短板; 提升

\section{1 目前形势}

自2017年开始, 水文测验质量评定检查工作在全国展开, 对水文数据 的准确性、精确性要求不断提升, 测验规范陆续更新, 对水文测验是一种挑 战, 也提出了更高的要求, 水文工作者需要不断纳入新知识, 水文管理者需 要剔除旧观念。如何提升基层水文测验工作水平, 提升基层水文测验队伍 建设, 提高对社会的服务能力成为基层水文工作者积极探寻的问题。

\section{1找差距}

一般基层水文工作者每天面临的工作比较单一、枯燥, 水位观测、流 量测验、泥沙测验、降水观测、蒸发观测等等基础性工作。如何将简单、 单一的工作进行成果转化, 形成系统、统一的成果, 是目前大部分基层水文 工作者所缺乏的。有很多基层水文工作者通过学习、总结、比武等各种形 式, 将自己的成果凝聚, 在这个平凡的岗位上做出了不平凡的业绩。

\section{2 寻短板}

一些基层水文工作者总是说自己基础差, 不想接触新事物、新仪器、 新方法, 大量的时间白白地流走。首先要从思想上重视学习, 学无止境, 时 代在发展, 知识在更新, 新时代对我们的要求不断提高, 我们需要做的是不 断学习, 补齐自己的短板, 能力不足是最大的恐慌。

\section{3列清单}

定学习计划, 列学习清单。对于基层水文工作者来说, 《规范》是必不 可少的工具书, 水文工作涉及的方面多, 各种规范层出不穷, 定期采购, 定 期学习更新知识是新时代对我们的要求, 指导该怎么做, 才能做得好。

\section{2 如何提高测验水平}

如何提升水文测验水平, 提高基层水文测验整体实力, 可以从以下几 个方面着手, 会获得较大收益, 形成良好风气, 将吃苦耐劳的水文精神一直 延续下去。

\section{1走出去}

学习是提高水平的有力武器, 水文测验是一个古老的学科, 很多知识 在更新, 走出去, 前往水文发展较快的地区、水文站调研学习, 开阔眼界, 拓展思路, 增长才干, 学习先进的管理手段, 不断提高管理水平。

\section{2 引进来}

测验人员自身应熟读水文测验规范, 对测验仪器的使用与数据的整理 了如指掌, 将新知识、新理念、新方法请进来, 加强自身学习, 学习更多相 关知识, 增强自身本领, 增强解决突发事件的意识和能力, 从理论到内业、 外业, 全方位学习, 以此提高水文测验人员自身水平。

\section{3 寻变革}

仅仅完成驻站的测验任务是无法提高测验水平的, 定期安排基层水文
测验人员至水文专业院校 (如河海大学、扬州水校等) 进修, 定期开展培 训、实战演练, 组织水文测验人员一起学习相关业务知识, 制定学习制度和 考核办法, 加强监管力度, 督促基层水文测验人员的学习主动性, 同时提升 大家的测验水平, 并且能够增强测验人员协作能力。

2. 4 促提升

积极开展调研, 引进更加先进的测验设备, 对测验人员进行使用培训, 通过对比使用, 掌握更先进更可靠的水文测验仪器设备, 这对提升测验水 平能产生显著作用, 对水文测验现代化的进程有一定的促进作用, 使基层 水文工作者有成就感、获得感, 从而不断提升自身本领。

\section{3 态度与能力}

就目前而言, 存在于测验人员之中的普遍问题就是态度问题, 部分测 验人员态度稍微懈急、不够积极, 对于新事物与新知识主观接受较慢, 无法 真正达到快速学习与接受的状态。当然, 每个人的能力有存在不同的状况, 确实会有人学习与接受能力较于他人更快的情况, 但是我相信只要有持续 学习的信心, 持之以恒的态度, 就能将这种差距无限缩小。总而言之, 一个 人的态度跟能力是与成效挂钩的, 只有端正态度, 才能不断提升自己的能 力。在这个日新月异的社会, 不至于过于 “能力恐慌”。同时, 态度比能力 更重要, 是基层水文工作者需要的更多的是那份坚守, 那份责任, 那份在没 有人监督的情况下的自觉与严谨。水文测验数据直接关系着工程运行、防 洪调度、领导决策, 要为自己提供的数据负责。

\section{4 预期效果}

经过以上几方面的提升与态度和能力的改正, 基层水文工作者的水平 可不断提高, 形成自主学习体系与督促考核机制, 引导基层水文工作者从 思想认识到切身感受, 热爱这份普通而不平凡的工作, 认识这份工作的重 要性, 在新时代中国特色社会主义思想的指引下, 将蒸蒸日上, 掀起一波学 习浪潮, 形式浓厚的学习气氛, 完成从基本到高层的成果转化局面。

\section{5 结语}

通过了解, 对目前基层水文测验现状进行分析, 为基层水文测验发展提 出了一些不成熟的观点与想法, 希望为今后的水文测验探出了一条更可行的 道路提供些许参考, 希望在今后的道路上, 基层水文测验工作将越来越好。

\section{[参考文献]}

[1]罗国平,水文测验 $[M]$. 北京:中国水利水电出版社,2017.3.

[2]朱晓原,张留柱,姚永熙.水文测验实用手册[M].北京:中国水利水电 出版社,2013:5.

[3] 林祚顶, 水文现代化与水文新技术 [M]. 北京: 中国水利水电出版 社,2008. 